\title{
PERCEPTIBILITY AND EXPERIENCE OF INNER-EUROPEAN BORDERS BY INSTITUTIONALISED BORDER PROTECTION
}

\author{
AndReAs PudLat \\ Hildesheim University, Institute of History, Germany
}

Manuscript received July 15, 2010

Revised version November 5, 2010

\begin{abstract}
Pudlat A., Perceptibility and experience of inner-European borders by institutionalised border protection. Quaestiones Geographicae 29(4), Bogucki Wydawnictwo Naukowe, Poznań 2010, pp. 7-13, 2 figs. DOI 10.2478/ v10117-010-0027-0, ISBN 978-83-62662-30-2, ISSN 0137-477X.
\end{abstract}

AвSTRACT. The article concentrates on institutionalised border protection as a special indication of border areas that are demarcated by the existence and operations of specific authorities. This kind of border protection with its control and monitoring measures serves different purposes, including crime fighting and protection against threats, fiscal aspects (customs), migration control, traffic safety, and environment protection. Furthermore, it is an expression of state sovereignty. In this way borders and border areas can be experienced and perceived, which the article suggests can have different dimensions: a cognitive, an affective, a visual-haptic, and an aesthetic one. Under the Schengen Agreement, systematic border control between the participating states has been removed. This implies, not the end of border protection, but perhaps a loss of a manifestation and perceptibility of borders and border areas.

KEY WORDS: border, border control, border protection, perceptibility, experience, Schengen Agreement

Andreas Pudlat, Institute of History, Hildesheim University, Tilsiter Straße 1, 31141 Hildesheim, Germany; e-mail: pudlat@uni-hildesheim.de

I.

The simple necessity and circumstance that people (or groups) need an identity and that this identity can only be established through contradictions and exclusions may be as old as mankind itself. Giving attention to such demarcations in contrast to physical space is a comparatively new phenomenon that appeared in the 17th century when countries that distinguished themselves were formed by the rounding off of their territories to a complete state with a clear border and people subordinated to the direct power of the state. England, France and The Netherlands were pioneers; being economically and coloni- ally successful, they required protection through a strong authority of the state. Prosperity, on the other hand, gave their populations a chance to benefit in the fields of consumption and politics. Despite aristocratic resistance and private interests, it also effected the centralization of power, which was equally claimed for the population and the area (Becker \& Komlosy 2004: 10).

Thus, in history borders manifested themselves as a more or less protective, dividing line between sovereign territories. Apart from that, they have both positive and negative characteristics. Keeping peace, maintaining security and order, ensuring discriminability and distinction as well as making a political and a geographical 
regional policy possible can be accompanied by less fortunate phenomena with a potential for conflict: borders are barriers to free trade and transport. Furthermore, they segregate others (Kroll 2004: 132).

In 1974, Guichonnet \& Raffestin (1974: 9) pointed out: "La frontière est un instrument géographique de différenciation et, par conséquent, en fin de compte, d'organisation de l'espace" (The border is a geographical instrument for the differentiation and, consequently, for the organisation of space). Although they seem to have anything but natural elements, borders are instruments of distinction and regional policy, which means they serve human, and therefore natural, needs. Borders are constructions and the expression of an attempt to control human life. To quote Georg Simmel (Lezzi 1994: 4): "Die Grenze ist nicht eine räumliche Tatsache mit soziologischen Wirkungen, sondern eine soziologische Tatsache, die sich räumlich formt" (The border is not a spatial circumstance implying sociological effects, but a sociological circumstance that forms itself spatially). For this reason borders have to be considered in isolation from natural circumstances and be understood as a result of human communication whose conditions are fixed by power relations on the strength of a treaty or by violence (Rüther 2007: 33). As a consequence, demarcations involve a high degree of randomness and have a changeable character. German history demonstrates this as well as the European integration process. Borders are constitutive elements of social life, but always negotiable and changeable, which is shown by the so-called Schengen process. Here, borders were not suspended per se, but their manifestation in the shape of institutionalised border protection. The states of the Schengen Group have therefore negotiated an acquis communautaire that has changed the practicability of borders and their significance for people's freedom of movement and the economy permanently.

\section{II.}

Malcolm Anderson, who understands borders from a political and a military point of view, stresses their nation-building and identity estab- lishing functions. He even refers to the important aspect of an institutionalised border protection linked with the existence of special authorities and their operations. Consequently, he defines the frontier as "the precise line at which jurisdictions meet, usually demarcated and controlled by customs, police and military personnel" (Anderson 1996: 9). These authorities indicate and label border areas. Moreover, they are a good reason for scientific consideration since borders help to protect the states not only in their sovereignty, but also in policing them. For this reason special staff is hired and trained by the police, the customs or even the military. Apart from this, special authorities responsible for border protection have been established. This means institutionalisation since those special authorities do not only work in short terms or on the basis of interpersonal relations. They have the imperative resources and clear rules to do their administrative job. Consequently, there is an institutionalised border protection if states decide to sign agreements about a certain kind of co-operation based on the law of nations, e.g. cross-border operations of their (border) police staff.

Institutionalised border protection with its control and monitoring measures serves different purposes. They include crime fighting and protection against threats, fiscal aspects (customs), migration control, traffic safety, and environmental protection.

Furthermore, it is an expression of state sovereignty. Migration control refers to entering or leaving a country; with the coming of the European Union the focus is rather on the regulation of immigration.

In this context, criminal law, especially for foreigners, has developed. Its targets are inner legal order, the capacity of state organisations to act, and especially social peace. In this case migration control combined with crime fighting serves the ability of the state to integrate.

Border protection can also be understood as a "business card" of state sovereignty. The state demonstrates its claim to power and signals its ability to fulfil its duties.

Border protection is often reduced to activities of authorities close to the borderline. They serve to check people's permit to cross the border and to control the import and export of goods. Check- 
ing persons who want to cross a border also includes making sure that they are not wanted by an authority, e.g. because of a crime. With this intention special databases are in use in which warrants of arrest or other requests are gathered. In this manner it is possible to arrest or watch criminals and to confiscate pieces of evidence or stolen things. Besides those control activities there are other important aspects of border protection, e.g. patrols and control in the hinterland, special operations, preliminary inquiries/ investigations, observations, public relation activities, cross-border cooperation between police forces, and deportations of "illegal" aliens. This means that border protection manifests itself not only close to the border. It is practised in the whole area of a state and especially in the spaces close to the borderline.

There is even a group of scientists who characterise space as an important, central and legitimising object or an anchor and an accepted methodological midway (Köck 1997: 89). Nevertheless, for quite a number of geographers the item "space" implies different meanings and concepts. Therefore, Benno Werlen has pleaded for focusing on the subject and its acts when analysing space geographically (Werlen 1987). His argumentation is sometimes misunderstood and he is characterised as a "space exorcist", but it is primarily against unreflecting space fetishism (Weichhart 1999: 68). To avoid this trap, this article defines the term "border area" not as an ontological, selfcontained structure, but as an address or a help to locate an area defined by a traversing borderline. This area can also be a result of a mental production performed by an individual person, a group, an organisation, an institution, or another social system. It includes delimitation and content-related connotation. Institutionalised border protection can also be part of this connotation. It is performed within the border area and manifests itself by border staff and its operations.

As a result, the border and the border area are going to be tangible for humankind in different dimensions: cognitive, affective, visual-haptic, and aesthetic. De facto a precise separation does not seem to be possible. On the contrary, these dimensions interfere and appear to be entangled.

The cognitive dimension extends to all facts and figures a single person or a group might be

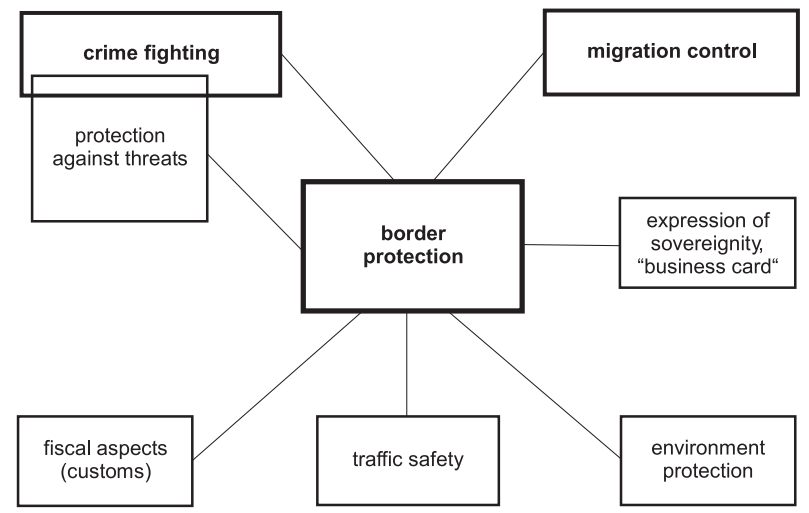

Fig. 1. Purposes of border control. Source: own compilation.

aware of. This can relate either to the boundary line or to its implications, for example:

- appropriate behaviour at the border (e.g. the obligation to use an official border-crossing point or the possibility to cross the border at any place),

- specific phenomena connected with border crossing (e.g. the control procedure performed by the border police or customs involving document checks or a search of persons and their belongings),

- how a border and the immediate areas are visible (e.g. landmarks, border-crossing facilities, demarcation by special authorities),

- the historical background and development of a border and its position in the past, present and future (e.g. border-related conflicts in society, international relations, cultural aspects, etc.), and

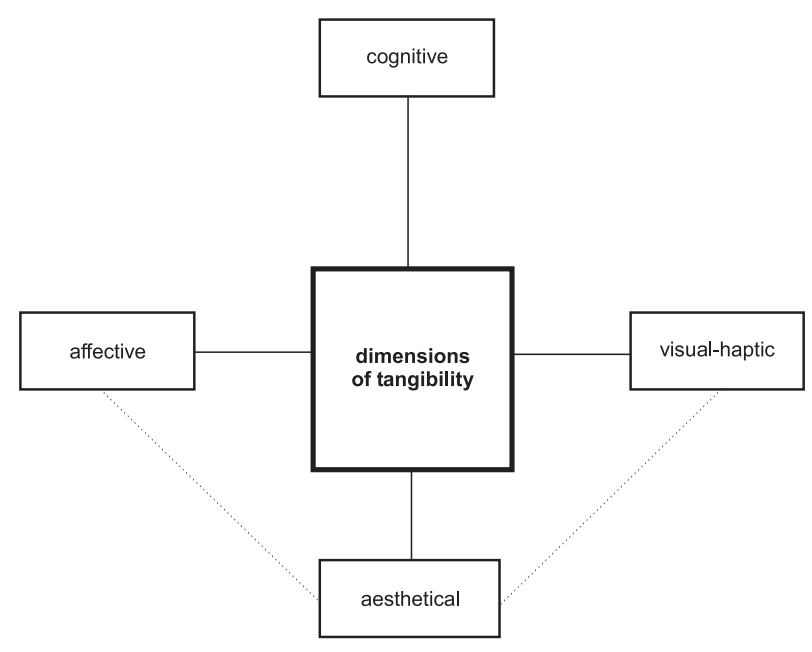

Fig. 2. Dimensions of tangibility. Source: own compilation. 
- phenomena that characterise the border area and are discussed in the media, by politicians and the people (e.g. the economic situation, stress of crime and police, a peripheral position).

The affective dimension implicates all feelings released by or related to thoughts on borders or the border and its experience. In this way a person can feel:

- welcome, in- or excluded,

- well or badly oriented, perhaps confused (e.g. because of the regional planning and situation),

- comfortable or uncomfortable with a foreign law system,

- burdened or unburdened by customs and taxes,

- satisfied or dissatisfied with the stretch of a border, its manifestation and protection (a good example is the negative feelings related to the "iron curtain"),

- in danger because of the protection regime at the border (e.g. because of snipers or an ineffective regime of border control),

- safe or unsafe in the hinterland because of the impression of (in)effective policing,

- comfortable or uncomfortable during the control procedures (e.g. because of the fear to be discovered as a criminal, the impression of a violation of privacy, the character of the event, or the manifestation of the foreign state or the homeland),

- anxious because of the length of control procedures, etc.

The visual-haptic dimension is related to the real physical experience and perceptibility of borders and means, for example:

- the active or passive physical experience of control procedures,

- the visual and/or haptic perceptibility of physical border manifestations (e.g. landmarks, signs, control facilities, personnel).

The aesthetic dimension can be regarded as a subcategory between the affective and the visual-haptic dimension. It combines the physical experience and perceptibility of borders with an aesthetic point of view.
III.

The long road to the Schengen Agreement, or the historical development of reducing border control in Europe, began already shortly after the Second World War. In films about Europe used as propaganda media to support the European integration process, borders and especially border control were already tainted with a negative image. Borders were considered to be a paragon of nationalism and therefore responsible for war, while border control was simply seen as a barrier to economic growth. Therefore, both items were already mentally questioned.

It therefore followed a certain logic that bilateral arrangements within international law were already signed in the 1950s, bringing a certain relief concerning border clearance. However, a common European area was still not on the agenda, although the Benelux countries, the Common Travel Area or the Nordic Passport Union already served as a kind of model for this (Pudlat 2009a, 2009b, 2009c.).

It was not until 1974 that nine heads of state and government of the European Community in Paris and the European Parliament sent a clear signal for the future. Instead of focusing on a predominantly economic project, the stated aim was now the creation of a "Europe for its citizens" including a passport union and gradually removed passport control. Subsequently, options, practicability, safety risks of a passport union and its legal basis became the questions discussed (Taschner 1997).

It was France and the Federal Republic of Germany that forced the pace of this long-winded process by signing the Saarbrücken Agreement on July $13^{\text {th }} 1984$. It stipulated a gradual removal of cross-border control between the two countries and gave the Benelux states motivation to suggest that the German and French governments adopt this agreement for all the common borders. The multilateral negotiations which followed led to another agreement between the five states on July $14^{\text {th }}, 1985$. This so-called Schengen Agreement was close to the Saarbrücken Agreement in terms of regulations and made all EC citizens benefit from it (Baumann 2006, 2008).

In order to institute control-free border crossing, several consultations between the interested 
countries were necessary as well as another agreement. As of June $19^{\text {th }}, 1990$ (and coming into force on September $\left.1^{\text {st }}, 1993\right)$, the Schengen Convention was the first agreement to abolish control of people at the internal borders of the signatories, to harmonise control at the external frontiers of the "Schengen area", and to introduce a common policy on visas and other accompanying measures, like police and judicial cooperation. Besides, it contained general provisions concerning entry for a stay not exceeding three months, obligations of the Member States as regards checks and surveillance, the liability of carriers, and the Schengen Information System (SIS).

The implementation of this agreement took place in March 1995 at the borders of nine countries: Belgium, France, Germany, Greece, Italy, Luxembourg, The Netherlands, Portugal, and Spain. Today, the Schengen area contains 25 members owing to the Central and East European enlargements of 2000 and 2007. There has also been juridical progress: the Schengen acquis was integrated into the EU treaties (Treaty of Amsterdam, 1997) and developed by the Schengen Borders Code in 2006. Police networking, which was closely connected with the Schengen acquis, has also made progress and has been discussed as Schengen III. In May 2005, seven Member States (Austria, Belgium, France, Germany, Luxembourg, Spain and The Netherlands) signed a treaty in Prüm to enhance cross-border police and judicial cooperation, especially on the fight against terrorism, cross-border crime, and illegal migration. For the states that are parties to it, the Prüm treaty serves as a basis for an automated comparison of database systems of the partner countries - because of data protection, so far only by way of a hit/no-hit procedures. In doing this, a fast recourse to vehicle, DNA and dactyloscopic (fingerprint) data is guaranteed. Furthermore, arrangements have been made to check document authenticity, cooperation combating terrorism, air security, deportation, and security for largescale events.

\section{IV.}

The absence of systematic control on the borders has led to misinterpretations in cognitive terms. Among the population, the removal of borders, which in fact continue to exist and define sovereign states, was and is partly accepted. Moreover, only a few people are aware of the exact rules of the Schengen agreement and especially the compensatory measures involved. But, above all it, was wrongly assumed that institutionalised border protection would be abolished. As has already been mentioned, it embraces more than just a systematic implementation of border control, which has only shifted to external borders rather than being completely abolished. This is also indicated by the fact that within the Schengen acquis there is an explicit control option between the states restricted to specific locations. Other border control activities are continued and partly strengthened: patrols and control in the hinterland, special operations, preliminary inquiries/ investigations, observations, public relation activities, cross-border cooperation between the police forces, and deportations of "illegal" aliens. Above all, police capabilities have been widened: cross-border observations and chases have been made possible as well as the exchange of data (fingerprints, DNA, vehicles) between those police authorities benefiting from the Treaty of Prüm. In particular, the Schengen process implies a significant increase in international police cooperation. In doing so, especially crime fighting and migration control should be pursued at a high level.

It is therefore surprising that at the affective level of e.g. the German and Austrian populations, a massive fear of crime has arisen. Consequently, border control is a factor influencing a population's sense of security. This finding has been corroborated by several studies. "Wenn es eine Forderung gibt, die in Zusammenhang mit der Kriminalitätsbekämpfung geradezu universal von den Bürgern vertreten wird, dann ist es die nach mehr Polizeipräsenz" (Where there is a universal demand for crime fighting, there is a greater presence of police), as Reuband (2004: 255) puts it. This demand is based on the intellectual link between crime reduction and a higher sense of security owing to police presence: wherever police is present, not only criminals are deterred but there is someone near that can be contacted in case of an emergency. Border areas are not seen as an exception. If there had been any 
negative feelings before the Schengen agreement came into effect, they have obviously given way to positive connotations: while border control means protection, its lack is also seen for what it really is: a relief for travelling owing to the elimination of waiting time.

Depending on the duration of border control absence, crucial changes can be found in the visual-haptic dimension. Representatives of the authorities are not visible anymore at any time. Their control activities directly at the border and at border crossing points are exceptional cases. According to the avowed aim of the Schengen process, the experience of being controlled has been repealed. Due to the Schengen Agreement, barriers have been dismantled, control facilities closed and partly demolished or redeveloped. As Jostmann \& Ctortecka (2009: 305) state: "Oft muss man nicht einmal die Geschwindigkeit drosseln, wenn man von einem Land ins andere übertritt, so dass die Grenze mit der Landschaft verschwimmt. Wer die europäischen Grenzen nach Schengen wahrnehmen will, braucht also entweder eine gewisse Langsamkeit, die des Spaziergängers oder Radfahrers etwa, oder er muss in der Nähe der Grenze leben und ihren Verlauf kennen, damit er sie noch erkennt" (It is often even not necessary to reduce speed when crossing the border from one country to another. The border blurs with the landscape. Whoever tries to perceive and recognise European borders after Schengen, either needs a certain kind of slowness like walkers and cyclists, or has to live near the border and know its stretch.) This means borders are not longer remarkable in any case. However, there are still some hints: a small landmark, inconspicuous signs, or even empty control facilities. These remnants have their own special charm and are able to appeal to an aesthetic sense of people. This is proved by photographs presented at the exhibition "Nach Schengen. Architektur und Ästhetik der Grenze" (After Schengen. The architecture and aesthetics of the border), or the web project "Schengen: Grenzen" (Schengen: The borders, www.schengen-grenzen.de) by Jostmann and Ctortecka, which presents photographs with details of control facilities before and after Schengen.

Border control as part of an institutionalised border protection is history, although an eye is still kept on certain borders. At least it has become exceptional. This is shown by the photographs. It does not mean the end of border protection itself, but an important change in its manifestation. This also has consequences for the experience and perceptibility of borders and border areas, at least in the Schengen area and the European Union. Borders as an important instrument of differentiation are visible to a lesser extent. Research is necessary to study the impact of this fact on identity building. But it is quite possible that the loss of the manifestation and perceptibility of borders and border areas due to the removal of border control means a chance for Europe to grow together and become more people-oriented.

\section{References}

Anderson M., 1996. Frontiers. Territory and state formation in the modern world. Cambridge.

Baumann M., 2006. Der deutsche Fingerabdruck. Die Rolle der deutschen Bundesregierung bei der Europäisierung der Grenzpolitik (The German fingerprint. The consideration of German government to Europeanizing the border policy). Baden-Baden.

BAUMANn M., 2008. Der Einfluss des Bundeskanzleramts und des Bundesministeriums des Innern auf die Entwicklung einer europäischen Grenzpolitik (The influence of the Office of the German Chancellor and the German Ministry of the Interior on the development of a European border policy). In: Hunger U., Aybek C.M., Ette A. \& Michalowski I. (eds), Migrations- und Integrationsprozesse in Europa. Vergemeinschaftung oder nationalstaatliche Lösungswege (The processes of migration and integration in Europe). Wiesbaden: 17-33.

Becker J. \& Komlosy A., 2004. Vorwort (Preface). In: Becker J. \& Komlosy A. (eds), Grenzen weltweit (Borders worldwide). Wien: 7-19.

Guichonnet P. \& RafFestin C., 1974. Géographie des frontières (Geography of frontiers), Paris.

Jostmann C. \& CTORTECKA B., 2009. "Nach Schengen. Architektur und Ästhetik der Grenze" - Anmerkungen zu einer Ausstellung ("After Schengen. Architecture and aesthetics of border" - Remarks to an exhibition). In: Gehler M. \& Pudlat A. (eds), Borders in Europe. Hildesheim, Zürich, New York: 305-326.

Kroll F.-L., 2004. Grenzen in der deutschen Geschichte (Borders in German history). In: E. Mehnert (ed.), Grenzpfade. Materialien zum 6. Deutsch-Tschechischen Begegnungsseminar. Gute Nachbarn - Schlechte Nachbarn? (Border paths. Materials of the $6^{\text {th }}$ German-Czech meeting seminar). Frankfurt/Main: 132-138.

KöcK H., 1997. Die Rolle des Raumes als zu erklärender und als erklärender Faktor. Zur Klärung einer methodologischen Grundrelation in der Geographie (The consideration of space as declaring and explaining factor. Clarification of a methodological basis relation in geography). Geographica Helvetica, 52: 89-96. 
LeZzi M., 1994. Raumordnungspolitik in europäischen Grenzregionen zwischen Konkurrenz und Zusammenarbeit. Untersuchungen an der EG-Außengrenze Deutschland-Schweiz (Regional planning policy in European border areas between competition and cooperation. Studies at the EC-border Germany-Switzerland), Zürich.

Pudlat A., 2009a. Grenzen ohne Polizei - Polizei ohne Grenzen? Überlegungen zu den Ambivalenzen des Schengen-Prozesses (Borders without police - police without borders? Thoughts about the ambivalance of Schengen process). In: Gehler M. \& Pudlat A. (eds), Borders in Europe. Hildesheim, Zürich, New York: 269-303.

Pudlat A., 2009b. Grenzräume und Polizeien - Überlegungen zum Schengen-Prozess und zu polizeilichen Raumkonstruktionen (Borders and police authorities. Thoughts about Schengen process and space constructions by the police). In: Köppen B.\& Horn M. (eds), Das Europa der EU an seinen Grenzen!? (The Europe of the European Union at its borders). Berlin: 69-94.

Pudlat A., 2009c. Schengen - Grenze - Polizei: Überlegungen zu den Grenzdiffusionen im Zuge der europäischen Integration (Schengen - border - police. Thoughts about border diffussion due to European integration). In: Behr R. \& Ohlemacher T. (eds), Offene Grenzen - Polizieren in der Sicherheitsarchitektur einer post-territorialen Welt (Open borders - Policing within the architecture of security in the post-territorial world). Frankfurt: 143-170.
Reuband K.-H., 2004. Steigert Polizeipräsenz das Sicherheitsgefühl? Eine vergleichende Studie in west- und ostdeutschen Städten (Increasing the feeling of safety by overexposure of police? A comparative study in Western and Eastern German cities). In: Schöch H., Jehle J.-M. \& Aebersold P. (eds), Angewandte Kriminologie zwischen Freiheit und Sicherheit (Applied criminology between freedom and security). Mönchengladbach: 255-272.

RÜTHER A., 2007. Flüsse als Grenzen und Bindeglieder (Rivers as borders and connective links). Jahrbuch für Regionalgeschichte (Annual on regional history), 25, Stuttgart: 29-44.

TASCHNER H.C., 1997. Schengen: Die Übereinkommen zum Abbau der Personenkontrollen an den Binnengrenzen von EU-Staaten (Schengen. The Agreements to remove the controls of persons at the borders between the member states of the European Union). Baden-Baden.

WeichHART P., 1999. Die Räume zwischen den Welten und die Welt der Räume. Zur Konzeption eines Schlüsselbegriffs der Geographie (Spaces between the worlds and the world of spaces. Contribution to a key concept in geography). In: Meusburger P. (ed.), Handlungsorientierte Sozialgeographie. Benno Werlens Entwurf in kritischer Diskussion (Action-oriented social geography. A critical discussion of Benno Werlens outline). Stuttgart: 67-94.

Werlen B., 1987. Gesellschaft, Handlung und Raum. Grundlagen handlungstheoretischer Sozialgeographie (Society, action and space. Basics of an action-oriented social geography). Stuttgart. 